\title{
HEGEMONI PEMERINTAH TERHADAP PEDAGANG PASAR (Analisis Dominasi Pemerintah Pasca Revitalisasi Pasar Kite Sungailiat Menurut Antonio Gramsci)
}

\section{Puspita Sari, Citra Asmara Indra, S.Sos., M.A.}

\begin{abstract}
Abstrak
Hegemoni merupakan dominasi atas satu kelas terhadap kelas lain disebabkan secara ideologis dan politis. Hegemoni dilakukan melalui mekanisme konsensus bukan dengan penindasan terhadap kelas sosial lain. Terdapat Hegemoni pemerintah terhadap pedagang pasar di Pasar Kite Sungailiat. Kekuasaan intelektual yang digunakan oleh pemerintah mampu mempengaruhi kesadaran pedagang untuk mengikuti kebijakan pemerintah. Pedagang yang merasa dirugikan dengan kebijakan tidak mampu untuk melakukan perlawanan. Perlawanan pedagang dapat diatasi pemerintah dengan membentuk konsensus antara pemerintah dan pedagang. Konsensus dilakukan untuk mempengaruhi pemikiran pedagang agar mengikuti aturan yang dibuat pemerintah
\end{abstract}

Kata Kunci : Hegemoni, Revitalisasi, Konsensus

\begin{abstract}
Hegemony is dominance of one class over another class, caused of repression against other social class.That the government's hegemony over market vendors in Pasar Kite Sungailiat area does exist. The intellectual power used by the government can affect the vendor's awareness to submit to the government's rules. Vendors who are disadvantaged by the policy are unable to fight back. The government can use consensus between the government and the vendors to handle the vendors resistance. This consensus can influence the opinion of the vendors so that they will obey the rules.
\end{abstract}

Keywords : Hegemony. Revitalization, consensus

\section{A. Latar Belakang}

Pasar tradisional menjadi tumpuan masya rakat saat ini kurang memiliki daya tarik jika dibandingkan dengan pasar modern yang semakin menjamur. Konsep pasar modern yang identik dengan kotor, kumuh, bau dan semrawut menyebabkan masyarakat tidak nyaman untuk berbelanja. Pasar modern yang teratur dan bersih menyebabkan masyarakat saat ini lebih memilih beralih dari pasar tradisional, walaupun harga di pasar modern jauh lebih tinggi dibandingkan dengan harga barang di pasar tradisional. Dalam meminimalisir kesenjangan antara pasar tradisional dan pasar modern, pemerintah kemudian mengadakan revitalisasi pasar.

Revitalisasi merupakan proses memvitalkan kembali suatu kawasan atau bagian yang dulunya pernah viral atau hidup, akan tetapi kemudian mengalami degradasi. Proses revitalisasi dan pembangunan dalam suatu kawasan mencakup perbaikan aspek fisik, aspek ekonomi dan aspek sosial (Sukriswanto, 2012: 14). Revitalisasi pasar berarti membangun kembali pasar tradisional yang semakin menurun daya tariknya bagi masyarakat kemudian menjadikannya pasar modern atau semi modern untuk kembali meningkatkan minat masyarakat terhadap pasar tersebut.

Namun, tidak seluruh revitalisasi pasar dapat berjalan dengan baik. Banyak kasus yang menyatakan revitalisasi pasar hanya akan merugikan pedagang dan memberikan keuntungan bagi pemerintah sebagai pemegang kendali pengelolaan pasar. Pemerintah mendominasi pengelolaan pasar dengan kekuatan intelektual 
yang dimiliki atau disebut hegemoni. Hegemoni merupakan istilah yang digunakan oleh Antonio Gramsci untuk menggambarkan suatu dominasi antar golongan satu atas golongan lain (Norrochman, 2008: 2). Hegemoni berhubungan dengan penyusunan kekuatan pemerintah sebagai klas diktator. Menurut Hegel, masyarakat diatur dan dikuasai oleh kapasitas intelektual super dari pemerintah yang merupakan tatanan tertinggi dari etika dan moral (Patria, 2015: 35).

Salah satu pasar tradisional yang melakukan revitalisasi pasar yaitu Pasar Kite Sungailiat. Pasar ini awalnya merupakan pasar tradisional yang kemudian dilakukannya revitalisasi menjadi pasar semimodern. Dalam proses revitalisasi pasar, terindikasi adanya hegemoni antara pemerintah terhadap pedagang pasar tersebut. Pemerintah membuat kesepakatan bersama pedagang yang seharusnya dilaksanakan dengan baik, namun realitasnya banyak pedagang yang tidak puas dengan hasil revitalisasi pasar.

Pasar Kite tidak mengalami perkembangan yang cukup baik seperti yang diharapkan dari hasil revitalisasi. Proses revitalisasi dirasakan tidak dapat menyelesaikan masalah yang ada di pasar tradisional bahkan menimbulkan masalahmasalah baru. Masalah ini antara lain terkait kondisi bangunan yang tidak sesuai, jumlah kios yang meningkat, hingga pembagian lapak yang tidak sesuai kesepakatan.

Pedagang secara sadar harus mengikuti peraturan pemerintah yang mengikat, lebih dari itu pedagang harus memberikan persetujuan terhadap peraturan dan kesepakatan yang dibuat oleh pemerintah. Namun disisi lain, pedagang memiliki kesadaran untuk terlepas dari dominasi pemerintah yang memaksa. Pemerintah sebagai golongan yang mendominasi berupaya mengambil keuntungan dari pedagang sedangkan pedagang tidak memiliki posisi tawar untuk melawan setiap kebijakan yang ditetapkan oleh pemerintah.

\section{B. Rumusan Masalah}

Melihat adanya hegemoni yang dibentuk oleh pemerintah terhadap pedagang pasar pasca revitalisasi, sehingga dapat dirumuskan masalah: Bagaimanakah bentuk-bentuk hegemoni yang dilakukan pemerintah terhadap pedagang Pasar Kite Sungailiat pasca revitalisasi?

\section{Kerangka Teori}

Teori Hegemoni milik Antonio Gramsci digunakan untuk menganalisis bentuk-bentuk hegemoni pemerintah terhadap pedagang Pasar Kite Sungailiat pasca revitalisasi. Istilah Hegemoni digunakan oleh Gramsci untuk menggambarkan bahwa dominasi satu kelas atas kelas lain disebabkan secara ideologis dan politis. Meskipun paksaan politik (coercion) selalu berperan, ideologi lebih signifikan dalam mendapatkan persetujuan secara sadar (consent) dari klas yang didominasi (Abercrombie, 2010: 253).

Hegemoni adalah sebuah rantai kemenangan yang didapat melalui mekanisme konsensus ketimbang melalui penindasan terhadap kelas sosial lain. Ada berbagai cara yang dipakai, misalnya melalui institusi yang ada di masyarakat yang menentukan secara langsung atau tidak struktur kognitif dari masyarakat. Pada hakikatnya Hegemoni merupakan upaya untuk menggiring orang-orang agar menilai dan memandang problematika sosial dalam kerangka yang telah ditentukan tanpa adanya paksaan secara kekerasan (Patria, 2015: 120-121).

Konsep hegemoni mendeskripsikan dan menganalisis bagaimana masyarakat kapitalis modern diorganisasikan. Menurut Gramsci, Hegemoni merupakan suatu kesatuan kompleks dari kegiatan teori dan praktek, yang dengannya klas yang berkuasa tak cuma membenarkan dan memelihara dominasinya tetapi mengatur untuk memenangkan konsensus aktif dari yang diatur. Dalam masyarakat kapitalis kontemporer, misalnya kelas pekerja memiliki kesadaran ganda (dual consciousness) kesadaran yang satu ditentukan oleh ideologi kelas kapitalis, kesadaran yang satu lagi revolusioner dan ditentukan oleh pengalaman mereka dalam masyarakat kapitalis. Dalam pandangan Gramsci, agar masyarakat kapitalis dapat digulingkan, kaum buruh harus terlebih dahulu menetapkan supremasi ideologi 
mereka sendiri yang diturunkan dari kesadaran revolusioner. Kesadaran ganda yang dimiliki oleh kelas yang didominasi menurut Lenin hanya merupakan perlawanan yang spontan dan masih bersifat palsu (Abercrombie, 2010: 253).

\section{Gambaran Umum}

Pasar Kite Sungailiat berada di Kelurahan Sungailiat Kecamatan Sungailiat. Pasar tradisional yang awalnya bernama Pasar Bawah ini merupakan pasar terbesar dan menjual berbagai jenis kebutuhan pokok dengan harga yang relative lebih murah. Pasar ini dibangun pada tahun 1970 dan belum pernah direnovasi sejak awal pembangunannya. Melihat kondisi bangunan pasar yang sudah tidak layak digunakan dan tidak dapat menampung jumlah pedagang yang semakin meningkat, pada tahun 2012 pemerintah daerah melalui Dinas Perindustrian, Perdagangan dan Koperasi Usaha Mikro Kecil Menengah (Disperindagkop dan UMKM) mengajukan rencana pembangunan pasar. Pengajuan dana ini akan digunakan untuk merevitalisasi pasar secara keseluruhan dan mengubah konsep pasar menjadi pasar semi modern.

Revitalisasi pasar digunakan untuk meningkatkan kualitas pelayanan pasar dan juga meningkatkan daya tampung pasar. Peningkatan jumlah lapak pasar dibuat untuk menampung sejumlah pedagang maupun PKL yang sudah lama berdagang di pasar. Revitalisasi pasar juga membantu pemerintah untuk mendata sejumlah pedagang yang sebelumnya belum terdata secara lengkap.

Jumlah pedagang yang terdata dalam proses pendataan yaitu 536 pedagang dari keseluruhan sekitar 1000 pedagang. Pedagang ini merupakan pedagang yang sudah belasan tahun berdagang di pasar. Data kemudian digunakan untuk memudahkan proses pembagian lapak atau kios pasar. keterbatasan luas lokasi pasar, menyebabkan jumlah lapak yang dapat dibangun sebanyak 607 lapak. Keseluruhan jumlah lapak ini dibagi dalam 10 jenis lapak dengan ukuran berbeda disesuaikan dengan jenis dagangan.
Pemerintah menganggarkan dana sebesar Rp 16 miliar untuk revitalisasi Pasar Kite Sungailiat dari Dana Bantuan (DABA) Pemerintah Provinsi Kepulauan Bangka Belitung. Pemerintah sebagai pengelola dana bertanggung jawab untuk mengelola dana pembangunan tersebut. Perencanaan pembuatan denah pasar dan penyusunan anggaran sama sekali tidak melibatkan pedagang. Keseluruhannya diatur oleh pemerintah melalui UPT Pasar dan Dinas PU. Hal ini meupakan salah satu bentuk Hegemoni yang dilakukan pemerintah terhadap pedagang pasar dimana pedagang tidak bisa mengontrol atau melihat sejauh mana perkembangan dari pembangunan pasar. Pedagang hanya bisa menyetujui apa yang telah dikerjakan oleh pemerintah sebagai pemegang kendali kekuasaan.

\section{E. Hasil dan Pembahasan}

Hegemoni merupakan bentuk dominasi pemerintah terhadap pedagang pasar. Dominasi yang dilakukan oleh pemerintah menggunakan kekuasaan intelektual yang dimiliki sehingga pedagang dengan sadar mengikuti keinginan pemerintah. Adapun bentuk-bentuk hegemoni yang dilakukan pemerintah terhadap pedagang pasar yaitu :

\section{Inisiasi dan proses revitalisasi pasar}

Pasar Bawah memiliki peran penting bagi perekonomian ratusan pedagang kecil yang menggantungkan hidupnya di pasar tersebut. Kondisi pasar yang memprihatinkan membuat pemerintah memutuskan untuk melakukan revitalisasi pasar secara keseluruhan. Proses revitalisasi pasar tidak secara langsung diterima oleh masyarakat khususnya pedagang Pasar Bawah. Butuh proses panjang yang dilakukan pemerintah untuk meyakinkan pedagang untuk menerima proses revitalisasi pasar.

Pedagang hanya meminta waktu 1 bulan sebelum pembongkaran pasar sampai selesai lebaran pedagang bersedia direlokasi sementara waktu namun, pemerintah tidak memikirkan kepentingan pedagang yang 
takut kehilangan konsumennya. Proses pembangunan tetap berjalan sesuai dengan rencana awal pemerintah. Pedagang sebagai kelas yang didominasi tidak dapat berbuat banyak. Aturan juga menjalankan kekuasaan hegemoni yang mampu melanggengkan kekuasan dari kelas dominan. Hegemoni selalu berhubungan dengan penyusunan kekuasaan pemerintah sebagai kelas diktator.

Pemerintah dengan segala aturan yang ada secara tidak langsung telah melanggengkan dominasinya terhadap pedagang. Kekuasaan yang dimiliki pemerintah digunakan untuk mendominasi pedagang sehingga pedagang harus mengikuti keinginan pemerintah. Pedagang tidak mampu menolak keinginan pemerintah dengan posisi tawar pedagang yang lemah. Pedagang harus tetap mengikuti keinginan pemerintah untuk pindah ke pasar sementara dan berharap tidak kehilangan konsumen mereka.

Pemerintah berusaha memperlihatkan kepada pedagang mekanisme pekerjaan mereka terkait pembangunan pasar. Pemerintah berulang kali harus mensosialisasikan kepada para pedagang terkait dengan aturan yang telah dibuat dalam proses revitalisasi pasar. pendekatan dengan kedekatan emosional seperti inilah yang digunakan pemerintah diawal proses revitalisasi agar para pedagang bersedia mentaati aturan-aturan yang telah dibuat oleh pemerintah.

Aturan yang dibuat merupakan alat untuk menjamin kedudukan kelas atas, yang fungsinya secara politik meredam usahausaha kelas bawah untuk membebaskan diri dari penghisapan oleh kelas atas. Aturan yang telah dibuat pemerintah ini kemudian membuat pedagang dengan kesadaran mengikutinya. Pemerintah menahan perlawanan pedagang dengan membuat aturan-aturan yang dengan kesadaran harus disetujui oleh pedagang.

\section{Penataan dan pembagian lapak}

Penataan dan pembagian lapak meru- pakan hal yang penting dalam proses revitalisasi pasar. Penataan lapak yang tidak sesuai dapat menyebabkan pasar menjadi tidak teratur dan kurang memiliki daya tarik. Pembagian lapak yang tidak adil juga akan membuat pedagang merasa dirugikan terlebih jika itu merupakan pedagang yang sudah lama berjualan di pasar. Penataan dan pembagian lapak harus dilakukan pemerintah dengan sesuai dan adil.

Penataan pasar sepenuhnya ditangai oleh pemerintah dalam hal ini pembuat desain pasar yaitu Dinas Pekerja Umum dan pihak pengembang. Penataan pasar disesuaikan dengan luas pasar yang tidak mengalami perubahan. Pemerintah meningkatkan jumlah lapak dan kios menjadi 607 buah. Jumlah lapak dan kios yang meningkat tentunya memperkecil ukuran lapak. Penataan lokasi lapak juga menjadi masalah lain. Pembangunan yang dilakukan dengan konsep kios dan lapak berderet menyebabkan banyak lapak yang lokasinya berada dibagian belakang. Hal ini tentunya menyebabkan banyak pembeli yang malas berbelanja ke bagian belakang terlebih dalam satu deretan kios atau lapak merupakan zona jenis dagangan yang sama.

Penataan kios dan lapak yang tidak tepat ini tentunya menyebabkan kerugian terlebih bagi para pedagang yang mendapatkan lokasi dibagian belakang. Apalagi pada saat pembuatan desain pasar, pemerintah sama sekali tidak melibatkan pedagang. Pedagang tidak bisa ikut campur dan hanya bisa menerima keputusan yang telah dibuat pemerintah selama pelaksanaan revitalisasi pasar. Untuk meminimalisir kekecewaan pedagang, pemerintah kemudian melakukan konsensus bersama perwakilan pedagang.

Pemerintah kembali melakukan konsesnsus bersama pedagang pada saat revitalisasi pasar sedang dilakukan. Konsensus kali ini berkaitan dengan kesepakatan pembagian lapak. Luas pasar yang tidak mengalami penambangan tentunya berdampak pada 
jumlah lapak pedagang yang tidak banyak bertambah sedangkan jumlah pedagang terus meningkat. Maka, pemerintah membuat strategi dalam pembagian lapak agar tidak ada protes dari pedagang.

Pada konsensus yang dilakukan di ruang serbaguna Polman, berisi kesepakatan terkait dengan pembagian lapak pasar. Melihat dari jumlah data pedagang pasar sudah dipastikan tidak semua pedagang akan mendapatkan lapak. Menurut Peraturan Mentri dalam negri tahun 2012 pasal 22 huruf a : memberikan prioritas tempat usaha kepada pedagang lama, dalam dilakukan renovasi dan/atau relokasi pasar tradisional.

Pedagang di Pasar Kite dibagi kedalam 3 kelompok yakni pedagang resmi, pedagang lama dan PKL. Pedagang resmi merupakan pedagang yang sudah memiliki kontrak bangunan di pasar dan izin usaha, pedagang lama merupakan pedagang yang sudah lama berjualan di pasar namun tidak memiliki izin usaha, dan PKL adalah pedagang yang berjualan diseputaran pasar baik dengan grobak atau lesehan, tidak memiliki lapak dagangan didalam bangunan pasar.

Konsensus ini kemudian memutuskan untuk memprioritaskan pembagian lapak kepada pedagang resmi dan pedagang lama, jika masih ada sisa lapak belum terisi baru akan dibagikan kepada PKL. Kesepakatan yang didapat pada konsensus terkait pembagian lapak ini yaitu pembagian lapak akan dilakukan dengan cara mengundi nama pedagang atau sistem cabut lot. Sistem ini merupakan sistem paling adil ketimbang penentuan dilakukan langsung.

Sistem cabut lot diutamakan bagi pedagang resmi dan pedagang lama terlebih dahulu, kemudian baru bagian untuk PKL. Pedagang resmi diprioritaskan karena mereka sebelumnya sudah memiliki kontrak dan lapak sendiri. Selanjutnya bagi pedagang lama yang tidak memiliki lapak, namun sudah berjualan puluhan atau belasan tahun di pasar. Sisa lapak yang masih ada barulah diperuntukkan bagi PKL atau pedagang baru. Pelaksanaan cabut lot dilakukan di kantor Disperindagkop dan UMKM Kabupaten Bangka dengan disaksikan oleh beberapa tokoh masyarakat dan kepala dinas terkait.

Strategi pembagian lapak ini dilakukan untuk mencegah protes dari pedagang jika mendapatkan lapak dilokasi yang tidak sesuai harapan mereka. Upaya lain yang dilakukan pemerintah untuk mendapatkan persetujuan pedagang dalam pembagian lapak yaitu dengan melakukan sosialisasi. Pemerintah melalui UPT Pasar setiap hari mendatangi pedagang dan mensosialisasikan terkait dengan pembagian lapak dan pembangunan pasar. Pendekatan dengan sistem ini akan memudahkan pemerintah untuk mendapat perhatian dan persetujuan dari pedagang.

Strategi yang digunakan pemerintah sebetulnya tidak berhasil sepenuhnya. Banyak pedagang lama yang masih belum mendapatkan lapak di pasar, selain itu pedagang juga mengeluh karena lokasi lapak yang tidak strategis. Pedagang lama yang sejak awal sudah memiliki izin di pasar merasa dirugikan karena banyak dari mereka malah mendapatkan tempat yang kurang strategis dalam pembagian lapak. Namun, pedagang tidak dapat berbuat banyak karena posisi tawar pedagang terlalu kecil untuk melawan dominasi pemerintah dalam penanganan pembagian lapak.

\section{Konsensus sepihak pemerintah terhadap pedagang}

Konsensus merupakan kesepakatan kata atau pemufakatan bersama mengenai pendapat, pendirian, yang dicapai melalui kebulatan suara. Konsensus dilakukan sebelum pengambilan keputusan atau pembuatan sebuah kebijakan. Konsensus menjadi titik tolak dari konsep hegemoni milik Antonio Gramsci. Gramsci memandang hegemoni adalah sebuah rantai kemenangan yang didapat melalui mekanisme konensus ketimbang melalui penindasan terhadap 
kelas sosial lainnya.

Kondisi pengelolaan Pasar Kite juga dilakukan pemerintah melalui jalan konsensus dengan pedagang. Pemerintah berupaya melakukan pembicaraan dalam pembuatan kebijakan pasar. Kepemimpinan intelektual pemerintah membuat keputusan yang dibuat pemerintah dalam konsensus dengan mudah diterima begitu saja oleh pedagang tanpa merasa pedagang akan banyak mengalami kerugian.

Gramsci lebih melihat hipotesis tercipta karena adanya dasar persetujuan. Sebuah konsensus yang diterima kelas pekerja sesungguhnya bersifat pasif karena sesungguhnya kelas yang terhegemoni kekurangan basis konseptual yang membentuk kesadaran yang memungkinkan mereka memahami realitas sosial secara efektif.Konsephegemoni secarafundamental menyangkut tindakan memproduksi suatu wawasan-dunia yang diterima oleh kelaskelas yang rendah dan beraliansi.

Hegemoni dapat diartikan sebagai suatu kepemimpinan intelektual dari pemerintah. Pemerintah tidak mendominasi pedagang dengan cara kekerasan, namun dengan melakukan pendekatan-pendekatan dan melakukan konsensus bersama pedagang pasar. Konsensus ini merupakan suatu konsensus sepihak yang dilakukan pemerintah terhadap pedagang pasar. Pedagang diharuskan menerima keputusan yang diambil dalam konsensus dengan kesadaran mereka, walaupun sesungguhnya pedagang tidak menginginkan hal tersebut. Pemerintah mampu membentuk suatu kebijakan baru atas dasar kesadaran dan kesepakatan dengan pedagang pasar meskipun pedagang tidak memahami efek kedepan dari kebijakan yang dibuat pemerintah.

Kelompok yang didominasi sesungguhnya memiliki kesadaran ganda, (dual consciousness), yaitu kesadaran ditentukan oleh ideologi dan kesadaran revolusioner. Kelas yang mendominasi masyarakat dengan kapasitas intelektual yang dimiliki. Kesamaan ideologi dibentuk melalui lembaga-lembaga seperti sekolah, tokoh masyarakat dan pemerintahan untuk menuntun masyarakat agar tidak melakukan perlawanan. Hal ini yang menyebabkan kesadaran revolusioner masyarakat tidak dapat dimunculkan.

Pemerintah sebagai kelas yang mendominasi masyarakat memiliki kepemimpinan intelektual. Pemerintah yang memiliki pendidikan tinggi mampu menggunakan bahasa untuk membentuk konsensus dalam masyarakat. Pemerintah dalam hal ini menggunakan bahasan dan kepemimpinan intelektual untuk mendapatkan persetujuan pedagang. Persetujuan yang dibentuk merupakan hasil dari kesadaran pedagang, bukan atas dasar paksaan pemerintah. Namun hal ini yang kemudian membuat pedagang banyak dirugikan terlebih dengan keadaan pasar yang tidak sesuai dengan keinginan pedagang.

Proses revitalisasi Pasar Sungailiat dilakukan selama setengah tahun dengan melalui proses yang panjang. Selama proses pembangunan pasar, pemerintah mencoba melakukan pendekatan dengan pedagang dan masyarakat melalui jalan konsensus. Konsensus diperlukan untuk memperoleh kesepakatan bersama terkait dengan kebijakan yang dibuat pemerintah. Konsensus juga digunakan untuk melihat peran aktif pedagang dalam pembangunan pasar.

\section{Kesukarelaan pedagang pengelolaan pasar}

Pasca revitalisasi mulai muncul protesprotes dari berbagai pihak. Protes ini berkaitan dengan kondisi fisik bangunan dan pengelolaan pasar. Pedagang banyak mengeluhkan kondisi bangunan yang tidak sesuai dengan anggaran yang sudah dikeluarkan oleh pemprov. Semua pendanaan sudah diatur dalam Rencana Anggaran Biaya 
(RAB) sesuai dengan kualitas dan jumlah barang. Namun pada pelaksanaannya banyak sekali barang yang tidak sesuai dengan apa yang tertulis didalam RAB.

Banyak protes dari yang dikemukakan oleh pedagang maupun masyarakat. Bahkan wakil ketua DPRD Bangka Belitung yang datang mengunjungi Pasar Kite Sungailiat juga protes dengan kondisi pasar. Dalam RAB dituliskan anggaran untuk kran air sebesar RP 85.000,- sedangkan kran yang digunakan hanya yang seharga Rp 5.000,. Selain kran air, keramik untuk lantai juga tidak sesuai dengan RAB. Keramik yang digunakan sangat licin dan tidak sesuai jika digunakan dilokasi pasar. Kondisi pasar yang becek menyebabkan banyak pembeli yang tergelincir hingga terjatuh akibat kondisi kramik yang licin (Bangkanew, 17 Januari 2016).

Kondisi bangunan yang tidak sesuai dengan RAB awal tentunya menurunkan kualitas bangunan pasar. Pedagang yang setiap harinya bekerja di pasar tentu kecewa ditambah lagi dalam proses pelaksanaan pembangunan pedagang tidak pernah dilibatkan. Bangunan pasar yang tertutup membuat suasana didalam pasar sangat panas karena kurangnya saluran udara. Pada musim hujan juga banyak bagian yang bocor. Pedagang mengeluhkan kurang baiknya pembangunan pasar karena belum setahun tapi bangunan sudah banyak yang rusak.

Pedagang merasa lebih nyaman dengan kondisi pasar lama jika dibandingkan dengan sekarang. Kondisi bangunan yang tertutup menjadikan pasar terkesan pengap dan panas pada musim panas. Pada saat musim hujan, banyak bagian yang bocor. Pedagang sudah melapor masalah ini kepada pihak pengelola pasar, plafon yang bocor sudah diperbaiki tapi baru seminggu diperbaiki bagian tersebut kembali bocor. Pengerjaan yang asal-asalan membuat pedagang kecewa dengan hasil pembangunan pasar. Namun sebagai pedagang kecil, mereka tidak bisa melakukan apa-apa karena pasar merupakan tempat penghidupan bagi para pedagang.

Masalah juga dirasakan dari ukuran lapak pedagang yang terlalu sempit terlebih pada bagian meja sayur, ikan, ayam dan daging. Ukuran lapak yang dibuat didalam bangunan utama pasar ini hanya $90 \mathrm{~cm} \mathrm{x}$ $155 \mathrm{~cm}$. Pedagang tentunya protes dengan kecilnya ukuran lapak. Pemerintah memang mengubah ukuran lapak yang awalnya 200 $\mathrm{cm} \times 150 \mathrm{~cm}$ agar pasar bisa menampung jumlah pedagang yang semakin meningkat. Tetapi dengan ukuran lapak sekarang, pedagang kesulitan meletakkan barang dagangan mereka terutama pedagang sayur.

Lapak dengan ukuran semakin diperkecil tentunya menyulitkan pedagang. Pedagang terpaksa meletakkan barang dagangan mereka dibawah dan sedikit menutup jalan pembeli. Tetapi saat ada pemeriksaan dari pihak keamanan para pedagang ini akan terkena sanksi. Sampai sejauh ini tidak ada upaya pemerintah untuk menangani keluhan pedagang pasar. Kekecewaan pedagang karena sejak awal mereka sudah menyampaikan aspirasi kepada pemerintah namun tidak ditanggapi. pedagang tidak bisa berbuat banyak, hanya mengikuti setiap kebijakan yang dibuat oleh pemerintah tanpa merasakan mereka telah dirugikan dengan hal tersebut.

Tata letak pembangunan kios juga menjadi masalah dalam pembangunan pasar. Kios-kios yang dibangun berjejer kebelakang sehingga banyak pengunjung malas untuk membeli ke kios dibagian belakang. Banyak pedagang yang berjualan di kios tersebut mengeluh sepi pembeli. Hal ini juga dirasakan oleh pedagang yang berjualan di pasar kampung bagian kanan pasar. Pasar kampung yang berada disudut pasar dengan ukuran lapak hanya $70 \mathrm{~cm}$ x $80 \mathrm{~cm}$ dengan akses jalan bagi pembeli terlalu sempit, akibatnya pembeli malas untuk masuk ke pasar kampung. Dampaknya bagi pedagang yaitu penurunan omset sehingga banyak 
pedagang yang mengeluh mereka selalu mengalami kerugian.

Pedagang yang sudah memiliki lapak tidak diperbolehkan menyewakan lapak atau kios mereka kepada orang lain. Kios yang sudah dikontrak harus digunakan langsung oleh pedagang yang memiliki kontrak bangunan tersebut. Ada 2 jenis harga yang harus dibayarkan oleh pedagang yakni uang sewa kios atau lapak dan uang retribusi harian. Uang sewa dibayarkan dalam setahun atau sesuai dengan kontrak yang telah dibuat. Jumlah yang harus dibayar disesuaikan dengan luas kios atau lapak. Pada meja dengan ukuran $90 \mathrm{~cm}$ x $155 \mathrm{~cm}$ ditarik tarif pertahun Rp 600.000,- untuk kios dengan ukuran $9 \mathrm{~m}^{2}-12 \mathrm{~m}^{2}$ ditarik tarif Rp 2.000.000,- dan kios dengan ukuran $4 \mathrm{~m}^{2}$ tarifnya Rp 650.000 per tahun (UPT Pasar Sungailiat).

Berkaitan dengan masalah retribusi ada 2 jenis retribusi yang ditarik oleh UPT Pasar yaitu retribusi jasa umum dan jasa usaha. Retribusi jasa umum tertulis dalam perda nomor 4 tahun 2011 bagian keempat pasal 54 ayat satu menjelaskan struktur dan besarnya tarif retribusi ditetapkan berdasarkan jenis, luas ukuran dan jangka waktu pemakaian dan masing-masing fasilitas serta kelas pasar yang digunakan. Tarif yang harus dibayarkan oleh pedagang sudah ditetapkan dalam perda tersebut dan dibayarkan setiap harinya. Selain retribusi jasa umum, setiap hari pedagang juga harus membayar pajak retribusi kebersihan dan keamanan sesuai peraturan yang telah ditetapkan oleh pemerintah.

Retribusi kebersihan dikelola oleh Badan Lingkungan Hidup (BLH) dan penarikannya diserahkan kepada UPT Pasar. walaupun sudah ada retribusi kebersihan, pedagang masih mengeluhkan kurangnya kepedulian pemerintah terhadap kebersihan pasar. Banyak sampah khususnya sisa sayuran yang menumpuk disekitaran belakang pasar dan dekat pasar kampung.
Petugas kebersihan dirasa kurang cepat untuk bertindak sehingga sampah terus menumpuk dan menyebabkan bau tidak sedap menyebar. WC umum juga menambah masalah bagi pedagang, saluran air yang kurang baik menyebabkan air dari WC mengalir keluar dan menimbulkan aroma tidak sedap.

Banyak pembeli yang mulai beralih ke Pasar Higenis yang pengelolaannya ditangani oleh pihak swasta. Pasar Higenis dikelola dengan baik, suasana lebih nyaman dan bersih jika dibandingkan dengan Pasar Kite. Hal serupa juga dikatakan oleh kepala Disperindagkop melalui Bangkapos. Pak Syarifudin pernah mengatakan kebersihan pasar memang kalah bersih dibandingkan Pasar Higenis, namun pemerintah sudah berupaya bekerja sama dengan pihak kebersihan dari Badan Lingkungan Hidup (BLH). Pemerintah juga menginginkan kerja sama dengan pedagang untuk menjaga kebersihan pasar (Bangkapos.com, 4 Agustus 2015).

Pembeli yang datang ke Pasar Kite mulai menurun. Kondisi pasar yang membuat pembeli kurang nyaman membuat banyak pembeli mulai beralih berbelanja di Pasar Higenis yang pengelolaannya lebih baik sehingga kondisinya lebih nyaman. Penurunan jumlah pembeli tentunya sangat berpengaruh dengan keuntungan yang diperoleh pedagang. Pada akhirnya pedagang harus rela mengurangi jumlah dagangan mereka ketimbang harus merugi karena jumlah dagangan selalu bersisa.

Banyak keluhan dari pembeli terhadap pembangunan pasar yang terlihat kacau. Apalagi jika melihat pengelolaan yang kurang diperhatikan pemerintah sehingga terkesan dibiatkan bergitu saja. Pembeli merasa kecewa dengan kondisi bangunan yang tidak lebih baik jika dibandingkan dengan kondisi pasar sebelum adanya renovasi. Hal ini pula yang membuat banyak pembeli yang beralih dari Pasar Kite ke 
pasar lain.

Pedagang pasar tidak dapat berbuat banyak dengan segala macam keluhan yang mereka hadapi. Pedagang mengikuti apa keinginan pemerintah agar mereka tidak kehilangan tempat bagi pedagang mencari nafkah. Gramsci menjelaskan bahwa konsep Hegemoni menganalisis bagaimana kapitalis modern diorganisasikan pada masa dulu dan sekarang. Pemerintah dalam hal ini mengorganisir para pedagang untuk mengikuti setiap aturan yang telah dibuat, dan membuat pedagang tidak dapat melakukan pembrontakan. Kepentingan kedua belah pihak menyebabkan pemerintah sebagai kelas diktator dapat mengontrol protes dari pedagang tanpa adanya kekerasan. Kekuatan intelektual yang dimiliki oleh pemerintah mampu melanggengkan kekuasaan pemerintah didalam masayarakat, yang dalam hal ini pedagang.

Pedagang yang kebanyakan merupakan orang dengan pendidikan rendah dengan mudah didekati oleh pemerintah dan secara sadar pedagang mengikuti saja keinginan pemerintah. Kerugian yang kebanyakan dirasa oleh pedagang yaitu perubahan desain pasar. Bangunan pasar yang dulunya terbuka membuat suasana didalam pasar tidak panas dan sumpek berbeda dengan sekarang pasar jadi lebih tertutup. Penambahan jumlah kios dengan susunan kios tidak sesuai menyebabkan pedagang yang mendapatkan kios dibelakang sangat dirugikan.

Melihat karakteristik pembeli yang ada di Bangka khususnya, mereka akan mencari kios atau lapak yang dekat jika dibandingkan harus berjalan terlalu jauh kebagian belakang. Ditambah dengan dibuatnya zonazona bagi pedagang, dengan bergabungnya banyak pedagang dengan jenis barang dagangan yang sama tentu pembeli akan mencari yang paling dekat dengan lokasi parkir kendaraannya.

Setelah berjalan beberapa lama, terdapat perlawanana yang dilakukan oleh pedagang Pasar Kite Sungailiat. Perlawanan ini dilakukan dengan spontan akibat dari kekecewaan pedagang terhadap pembangunan dan pengelolaan pasar.Bentuk perlawanan yang dilakukan hanya sebatas protes pedagang terhadap kebijakan yang dibuat pemerintah dan dirasakan merugikan pedagang.

Bentuk perlawanan pedagang terhadap kebijakan pemerintah hanya sebatas protesprotes yang mereka sampaikan.Pedagang memilih untuk berjualan disepanjang lorong pasar sebagai protes mereka dan memilih meninggalkan kios yang sudah dikontrak. Pedagang memang tidak bisa berbuat banyak ditambah dengan kurangnya asosiasi pedagang.Pedagang tidak memiliki posisi tawar yang baik sehingga banyak pedagang kecewa dengan pengelolaan yang dilakukan oleh pemerintah.

Perlawanan yang dilakukan pedagang hanya bersifat sementara dan terus berulang. Pedagang akan berjualan disepanjang lorong pasar, tetapi saat adanya penertiban mereka akan kembali ke lapak mereka. Pemerintah tidak pernah melakukan kekerasan dalam penanganan pedagang.Pemerintah berusaha melakukan pendekatan untuk menimbulkan kesadaran pedagang.Namun tetap saja pemerintah tidak bisa memberikan solusi terbaik bagi keadaan pedagang.Pedagang harus mau mengikuti aturan yang telah dibuat oleh pemerintah walaupun dalam aturan tersebut memang tidak ada sanksi tertulis bagi pelanggarnya.Disinilah muncul kesukarelaan pedagang untuk mengikuti aturan pemerintah dalam pengelolaan Pasar Kite Sungailiat.

\section{F. Penutup}

Konsep revitalisasi Pasar Kite Sungailiat yaitu dengan pembangunan berbasis masyarakat dimana yang menjadi perhatian adalah keinginan masyarakat. Namun yang terjadi, pembangunan yang dilakukan merupakan pembangunan dari atas dimana pemerintah mengambil alih seluruh 
proses pembangunan dan membuat kebijakan tanpa memperhatikan aspirasi pedagang. Pemerintah merupakan kelas yang mendominasi dalam pengelolaan pasar sehingga segala aturan dan kebijakan yang dibuat pemerintah harus diikuti oleh pedagang.Pedagang memiliki kesadaran ganda yang terbentuk dari kesadaran yang dipengaruhi oleh pemerintah dan kesadaran revolusioner dari keseharian yang dilakukan pedagang.

Bentuk hegemoni yang dilakukan pemerintah terhadap pedagang yakni : (a) Sejak awal pedagang menolak adanya revitalisasi Pasar Bawah. Pemerintah kemudian melakukan berbagai upaya untuk meyakinkan pedagang dalam melaksanakan revitalisasi pasar. Pendekatan dilakukan pemerintah dengan cara sosialisasi dan konsensus untuk mendapatkan persetujuan pedagang. Hal ini menunjukkan bentuk hegemoni pertama yang dilakukan pemerintah dalam upaya revitalisasi pasar. (b) Hegemoni dilakukan pemerintah dalam upaya pembagian lapak. Proses pembagian lapak pedagang dilakukan dengan sistem cabut lot sebagai aturan yang ditetapkan pemerintah untuk meredam protes pedagang nantinya. Sebagai titik tolak dari konsep hegemoni, konsensus merupakan jalan pendekatan untuk membentuk kesepakatan secara sadar dari pedagang tanpa melakukan paksaan. Terlebih dengan gaya kepemimpinan pemerintah yang intelektual membuat pedagang cepat membentuk kesadaran tersebut. (c) Konsensus dilakukan pemerintah sebagai titik tolak dari hegemoni pemerintah. Pemerintah berupaya melakukan pendekatan dengan pedagang melalui jalan konsensus. Konsensus ini dilakukan secara sepihak antara pemerintah terhadap pedagang pasar.Pemerintah berupaya untuk mendapat persetujuan pedagang secara sadar sedangkan pedagang pasar tidak memiliki posisi tawar untuk menentang. (d) Pedagang sebagai pihak yang didominasi harus dengan sadar mengikuti setiap kebijakan dan aturan yang telah ditetapkan oleh pemerintah walaupun disisi lain pedagang memiliki kesadaran untuk melakukan perlawanan. Pedagang dengan sukarela mengikuti aturan yang sudah dibuat pemerintah, walau aturan tersebut tidak memberikan sanksi yang tegas bagi pelanggar aturan.

Sampai kapan pun, Hegemoni pemerintah terhadap pedagang tidak akan pernah berakhir dan akan terus berjalan. Pedagang akan terus berada dibawah bayang-bayang aturan yang dibuat pemerintah meskipun sebetulnya pemerintah tidak mengetahui keinginan sesungguhnya dari pedagang pasar.

\section{DAFTAR PUSTAKA}

Abercrombie, Nicholas.dkk. 2010. Kamus Sosiologi. Terjemahan oleh Desi Novianti. Yogyakarta : Pustaka Pelajar.

Bocock, Robert. 2007. Pengantar Komprehensif Untuk Memahami : Hegemoni. Yogyakarta : Jalasutra.

Legowo, Martinus.dkk. 2008. Pedagang dan Revitalisasi Pedagang Tradisional di Surabaya : Studi Kasus pada Pasar Wonokromo dan PAsar Tambah Rejo, Surabaya. Jurnal.Fakultas Ilmu Sosial Universitas Surabaya.

Malano, Herman. 2011. Selamatkan Pasar Tradisional.Jakarta : Gramedia Pustaka Utama.

Patria, Nezar dan Andi Arif. 2015. Antonio Gramsci : Negara \& Hegemoni. Yogyakarta : Pustaka Pelajar.

Sukriswanto, Ucang. 2012. Analisis Kelayakan Revitalisasi Pasar Umum Gubug Kabupaten Grobogan. Jurnal.Universitas Negri Yogyakarta.

Theresia, Aprilia. 2014. Pembangunan Berbasis Masyarakat (Acuan Bagi Praktisi, Akademisi, dan Pemerhati Pengembangan Masyarakat). Bandung : Alfabeta. 
Bangkapos. 14 April 2015. Ini Kisah Pasar Kumuh Jadi Pasar Kite Sungailiat.Diakses pada 21 Oktober 2015.http://bangka. tribunnews.com/2015/04/14/ini-kisahpasar-kumuh-jadi-pasar-kite-sungailiat

Bangkapos.7 Oktober 2015.Pedagang Pasar Kite yang Jualan di Lorong Diminta Kembali ke Lapaknya.

RRI.20 Oktober 2015.Pedagang Pasar Kite Sungailiat Tinggalkan Petak Kios Beralih ke PKL.Diakses pada 21 Oktober 2015. http://www.rri.co.id/post/berita/210986/ ekonomi/pedagang pasar kite sungailiat tinggalkan petak kios beralih ke pkl.html 